\title{
Zjawisko deprywacji słuchowej u osoby dorosłej z postlingwalnym ubytkiem słuchu. Studium przypadku
}

\section{The phenomenon of auditory deprivation in adults with postlingual hearing loss: a case study}

\author{
Anna Kostecka, Zdzisław Marek Kurkowski \\ Zakład Logopedii i Językoznawstwa Stosowanego UMCS, ul. Sowińskiego 17, 20-040 Lublin
}

Adres autora: Anna Kostecka, Zakład Logopedii i Językoznawstwa Stosowanego UMCS, ul. Sowińskiego 17, 20-040 Lublin; e-mail: kost_ania@autograf.pl

\begin{abstract}
Streszczenie
Wprowadzenie: Zdolność do odbierania wielu wrażeń słuchowych w krótkim czasie wynika z psychofizjologicznych możliwości człowieka. Wrażenia słuchowe nie są wyłącznie wynikiem biernego odbioru bodźców zewnętrznych, lecz są zdeterminowane indywidualnymi doświadczeniami słuchowymi jak również procesami aktualnie zachodzącymi wewnątrz organizmu człowieka. Badania nad spostrzeganiem dźwięku wchodzą w zakres problematyki percepcji dźwięków mowy i otoczenia. W sytuacji gdy do ośrodkowego układu nerwowego przez dłuższy czas nie dociera wystarczająco wiele bodźców, dochodzi do stopniowej utraty umiejętności ich przetwarzania. Zaburzenia w tym zakresie powodują zjawisko deprywacji słuchowej, która manifestuje się trudnościami w odbieraniu dźwięków na drodze słuchowej, rozumieniu mowy a także w konsekwencji porozumiewaniu się międzyludzkim.
\end{abstract}

Cel: Celem pracy jest przedstawienie istoty deprywacji słuchowej u osoby dorosłej z postlingwalnym ubytkiem słuchu. Ukazanie przyczyn i konsekwencji tego zjawiska w życiu codziennym, funkcjonowaniu na różnych poziomach: poznawczym, emocjonalnym, komunikacyjnym, a także propozycja terapii logopedycznej.

Materiał i metody: Badania logopedyczne dotyczą osoby dorosłej z postlingwanym ubytkiem słuchu korzystającej z systemu implantu ślimakowego. Wykorzystanie studium indywidualnego przypadku pozwoliło na postawienie rzetelnej diagnozy, a także skonstruowanie ramowego programu terapii dopasowanej do potrzeb badanej osoby niesłyszącej. W przebiegu badań osoby dorosłej przedstawianej w artykule oprócz wywiadu i obserwacji wykorzystano analizę dokumentacji medycznej, która dostarczyła informacji dotyczących historii choroby pacjentki. Prezentowane badania mają charakter jakościowy. Uwzględniają kontekst sytuacyjny badanych zjawisk gdzie istotne jest poznanie ich rozwoju w warunkach naturalnych. W omawianym przypadku dokonano analizy realizacji systemu fonologicznego pod względem cech segmentalnych (artykulacja samogłosek i spółgłosek) i suprasegmentalnych - intonacja, rytm, akcent. Oceny intonacji dokonano na podstawie wypowiedzi osoby badanej biorąc pod uwagę analizę audytywną - subiektywną ocenę słuchową a także akustyczną analizę wykresów przebiegu linii intonacyjnej z wykorzystaniem programu komputerowego Wave Surfer 1.8. Dodatkowo zastosowano Profil Stuchowych Umiejętności Pacjentów Implantowanych (Skarżyński i wsp. 2004) opracowany przez specjalistów Instytutu Fizjologii i Patologii Słuchu i Mowy w Kajetanach.

Wyniki: Zdobyte umiejętności słuchowe osoby badanej z Profilu Umiejętności Słuchowych Pacjenta wskazują na przeciętne osiągnięcia badanej osoby w zakresie dyskryminacji, identyfikacji, a także rozumienia dźwięków mowy i otoczenia. Utworzony profil pozwolił na skonstruowanie indywidualnego programu terapii, którego celem jest rozwijanie umiejętności słuchowych badanej osoby niesłyszącej przede wszystkim na drodze słuchowej. Z analizy realizacji systemu fonologicznego wynika, że kontur intonacyjny badanej osoby niesłyszącej jest płaski i monotonny. W opisie zaburzeń prozodycznych zauważono wyraźną tendencję do skandowania pojedynczych wyrazów, z pauzami międzywyrazowymi. Zdania rozkazujące, wykrzyknikowe i pytające występują w postaci realizacji zdań twierdzących. Badana osoba niesłysząca w porównaniu z osobą słyszącą nie intonuje w sposób poprawny zdań rozkazujących jako kadencja, zdań wykrzyknikowych w postaci intonacji opadającej oraz zdań pytających jako antykadencja.

Wnioski: Biorąc pod uwagę wyniki badań należy stwierdzić, że zjawisko deprywacji słuchowej u badanej osoby niesłyszącej występuje na skutek braku stymulacji słuchowej przez długi okres czasu. Prawdopodobnie w prezentowanym przypadku ze względu na niekorzystanie $\mathrm{z}$ aparatów słuchowych do ośrodkowego układu nerwowego przez dłuższy czas nie docierało $\mathrm{z}$ uszu wystarczająco wiele bodźców akustycznych co spowodowało stopniową utratę umiejętności ich przetwarzania. Deprywacja 
słuchowa u badanej osoby przejawia się w postaci braku rozumienia mowy na drodze słuchowej a także jest konsekwencją późnej operacji wszczepienia systemu implantu ślimakowego (53 rok życia). Aktualnie percepcja badanej osoby niesłyszącej opiera się głównie na kanale wzrokowo-słuchowym. Mowa jej jest charakterystyczna dla osób z postlingwalnym ubytkiem słuchu. Występują zaburzenia artykulacji na tle niedosłuchu - dyslalia audiogenna, a także zakłócenia elementów prozodycznych wypowiedzi: intonacji, akcentu i rytmu.

Konstruując ramowy program terapii wzięto pod uwagę wyniki badań diagnostycznych bazując na Profilu Umiejętności Słuchowych (Skarżyński i wsp. 2004) i posłużono się nim jako punkt wyjścia do tworzenia procesu rehabilitacji.

Metody terapii jakie zastosowano w przypadku osoby dorosłej z objawami deprywacji słuchowej to przede wszystkim intensywny trening słuchowy bazujący na dyskryminacji i identyfikacji, a także rozumieniu mowy bodźców akustycznych na drodze słuchowej. Ramowy program terapii zawiera również propozycję ćwiczeń logopedycznych z zakresu emisji głosu, techniki mówienia począwszy od relaksacji, wypracowania właściwej postawy ciała, poprzez ćwiczenia oddechu, fonacji i artykulacji aż do ćwiczeń poprawnej prozodii wypowiedzi.

Słowa kluczowe: deprywacja słuchowa • system implantu ślimakowego • diagnoza logopedyczna

\begin{abstract}
Introduction: The ability to receive multiple listening experiences in a short time results from psychological and physiological possibilities of a man. Listening experience is not only the result of passive reception of external stimuli, but is determined by individual experience of hearing as well as the processes currently taking place inside the human body. Research on the perception of sound belongs to the scope of the problems of perception of speech sounds and environments. When the central nervous system for a long time does not receive enough incentives from one ear, there is a gradual loss of ability to analyze them. Disturbances in this field cause the phenomenon of auditory deprivation, which is manifested by difficulties in receiving sounds through hearing, understanding speech and communication problems among people.
\end{abstract}

Target: The aim of this paper is to present the essence of auditory deprivation in adults with postlingual hearing loss, to reveal the causes and consequences of this phenomenon in everyday life and in the functioning at different levels: cognitive, emotional and communicative, as well as to offer a speech therapy proposal.

Materials and methods: The research concerned an adult with postlingual hearing loss the cochlear implant system. The use of case study allowed for a reliable diagnosis and therapy program to construct the therapeutic framework tailored to the needs of the deaf person. During the studies on the tested adult, apart from interviews and observations also the analysis of medical records was used, which provided information on the patient's medical history. The presented research is qualitative. It takes into account the situational context of the studied phenomena, where it is important to get to know their development under natural conditions. In the considered case, the analysis was performed of the implementation of the phonological system in terms of its segmental features (articulation of vowels and consonants) and suprasegmental ones - intonation, rhythm and accent. Evaluation of the intonation was based on the basis of an utterance of the person examined, taking into account the auditory analysis: subjective listening assessment as well as acoustic analysis of the charts of intonation course using the computer program Wave Surfer 1.8. In addition, Hearing Skills Profile of the Implanted Patients was used (Skarzynski et al. 2004) developed by the specialists of the Institute of Physiology and Pathology of Hearing and Speech in Kajetany.

Results: The listening skills of the person tested in the Hearing Skills Profile of a Patient indicate the person's average achievements in the field of discrimination, identification and comprehension of speech and environmental sounds. The Profile allowed for the construction of an individual therapy program, which aimed to develop the listening skills of a deaf person in the auditory pathway only. The analysis of the implementation of the phonological system showed that the intonation contour of the tested deaf person was flat and monotonous. In the description of prosodic disturbances a clear tendency was observed to chant single words with pauses between the words. Imperative, exclamatory and interrogative sentences were in the form of implementation of affirmative sentences. The study has shown that a deaf person, unlike a hearing person, cannot correctly chant imperative statements as cadence, exclamation sentences in the form of a falling intonation or interrogative sentences as anticadence.

Conclusions: Taking into account the results of research it should be noted that the phenomenon of auditory deprivation in deaf people results from a lack of auditory stimulation over a long period of time. Probably in the presented case the central nervous system for a long time had not received enough acoustic stimuli from ears, and therefore there was a gradual loss of ability to analyze them. It is manifested by the lack of understanding of speech in the auditory pathway. Auditory deprivation of the examined person has also been the consequence of late implant surgery of cochlear implant system (at 53 years). Currently, the tested deaf person relies heavily on visual-auditory pathway. Her speech is typical for people with postlingual hearing loss. Problems with articulation have appeared due to hearing loss - audiogenic dyslalia and disturbances in the prosodic elements of speech, intonation, accent and rhythm.

While constructing the framework program of therapy, the results of diagnostic tests were considered based on the Hearing Skills Profile (Skarzynski et al. 2004) and the latter was used as a starting point for the rehabilitation process creation. 
The therapies used for an adult with symptoms of auditory deprivation are primarily an intensive listening training based on the discrimination and identification, as well as understanding speech acoustic stimuli on the auditory pathway. Therapy for an adult with symptoms of auditory deprivation consists primarily in intensive listening. The framework program also contains a proposal of speech therapy practice in the field of voice emission, speaking techniques ranging from relaxation and developing proper posture, through breathing exercises, phonation and articulation to the proper exercise of speech prosody.

Key words: auditory deprivation $\bullet$ postlingual hearing loss $\bullet$ cochlear implant system $\bullet$ diagnosis and therapy of speech

\section{Wstęp}

Do układu słuchowego nieustannie dociera ogromna liczba dźwięków. Zdolność do odbierania wielu wrażeń słuchowych w krótkim czasie wynika z psychofizjologicznych możliwości człowieka. Wrażenia słuchowe nie są wyłącznie wynikiem biernego odbioru bodźców zewnętrznych, lecz są także zdeterminowane indywidualnymi doświadczeniami słuchowymi jak również procesami aktualnie zachodzącymi wewnątrz organizmu człowieka. Badania nad spostrzeganiem dźwięku wchodzą w zakres problematyki percepcji dźwięków mowy i otoczenia. W sytuacji gdy do ośrodkowego układu nerwowego przez dłuższy czas nie dociera z jednego ucha wystarczająco wiele bodźców, dochodzi do stopniowej utraty umiejętności ich analizy. Zaburzenia w tym zakresie powodują zjawisko deprywacji słuchowej, która manifestuje się trudnościami w odbieraniu dźwięków na drodze słuchowej, rozumieniu mowy a także problemami w porozumiewaniu się międzyludzkim.

W przypadku głębokiego obustronnego, postlingwalnego niedosłuchu dużą rolę odgrywa wczesne wszczepienie systemu implantu ślimakowego, zwiększającego zasięg informacji dochodzących drogą słuchową. Ma to ogromny wpływ na rozumienie mowy oraz pozwala osiągnąć osobie, przy dodatkowej i systematycznej rehabilitacji polepszenie funkcjonowania w sytuacjach życia społecznego.

Biorąc pod uwagę ważność powyższych zagadnień autorka niniejszej pracy chce się podzielić własnymi spostrzeżeniami dotyczącymi diagnozy i terapii logopedycznej w przypadku osoby dorosłej niesłyszącej z systemem implantu ślimakowego.

\section{Material i metody}

Podstawową metodą stosowaną w badaniach logopedycznych jest metoda indywidualnego przypadku. Metoda ta opiera się na analizie jednostkowych losów ludzkich uwikłanych w sytuacje wychowawcze lub na analizie konkretnych zjawisk natury wychowawczej poprzez pryzmat jednostkowych biografii ludzkich z nastawieniem na opracowanie diagnozy przypadku lub zjawiska w celu podjęcia działań terapeutycznych [Pilch., Bauman, 2001]. Metoda indywidualnego przypadku w logopedii prowadzona jest w celu postawienia rzetelnej diagnozy a także odpowiedniego doboru terapii.

W prezentowanej pracy zastosowano: wywiad i obserwację dorosłej osoby niesłyszącej. Wykorzystano także analizę dokumentacji medycznej, która dostarczyła informacji dotyczących historii choroby badanej osoby. Przedstawione badania mają charakter głównie jakościowy. Uwzględniają kontekst sytuacyjny badanych zjawisk gdzie istotne jest poznanie ich rozwoju w warunkach naturalnych.
W omawianym przypadku przeprowadzono analizę fonetyczną pod względem cech segmentalnych (artykulacja samogłosek i spółgłosek) i suprasegmentalnych - intonacja, rytm, akcent. Oceny intonacji dokonano na podstawie wypowiedzi osoby badanej biorąc pod uwagę analizę audytywną - subiektywną ocenę słuchową a także akustyczną analizę wykresów przebiegu linii intonacyjnej (pitch conture) $\mathrm{z}$ wykorzystaniem programu komputerowego Wave Surfer 1.8. Weryfikowano przebieg linii intonacyjnych występujących w trzech rodzajach zdań, zgodnie z typologią B. Wierzchowskiej (1971): twierdzącym (intonacja rosnąco-opadająca), pytającym (antykadencja), rozkazującym (kadencja) oraz wykrzyknikowym (intonacja opadająca) w porównaniu do wypowiedzi osoby słyszącej z poprawną artykulacją. Wykorzystano w tym celu zestaw zdań w opracowaniu własnym.

Dodatkowo zastosowano Profil Stuchowych Umiejętności Pacjentów Implantowanych [Skarżyński i wsp. 2004] opracowany przez specjalistów Instytutu Fizjologii i Patologii Słuchu i Mowy w Kajetanach. Zdobyte umiejętności słuchowe osoby badanej zostały przedstawione graficznie w postaci Profilu Umiejętności Słuchowych Pacjenta. Indywidualny postęp w rozwoju funkcji słuchowych, weryfikowano na podstawie trzech poziomów zawartych w profilu: I poziom podstawowy, II poziom zwykłej rozmowy, III poziom rozumienia mowy. Każdemu z nich przyporządkowano wybrane testy, których wyniki, stanowiły procent poprawnych odpowiedzi. Profil posłużył jako punkt wyjścia do skonstruowania programu terapii dopasowanego do potrzeb badanej osoby niesłyszącej.

\section{Wyniki}

U badanej osoby został zdiagnozowany obustronny, głęboki niedosłuch odbiorczy (zmysłowo-nerwowy). Z wywiadu ustalono, że pacjentka w dzieciństwie chorowała na odrę. Powikłaniem tej choroby w 12 roku życia była również perforacja subtotalna błony i destrukcja kosteczek słuchowych w uchu prawym a także totalna perforacja i destrukcja kosteczek słuchowych w uchu lewym. Badana osoba niesłysząca w 2005 roku została skierowana na operację rekonstrukcyjną (myringoplastykę) ucha prawego w celu umożliwienia wszczepienia systemu implantu ślimakowego. Myringoplastykę zastosowano u pacjentki obustronnie.

Pacjentka jest użytkownikiem systemu implantu ślimakowego od 2003 roku. Badana miała wtedy 53 lata. System implantu ślimakowego jaki zastosowano u osoby badanej w uchu prawym to typ MED-EL COMBI 40+. Warto zaznaczyć fakt, że pacjentka wcześniej nie korzystała z tradycyjnych aparatów słuchowych. Badana przebywała w „ciszy” przez okres ok. 30 lat. Pacjentka stopniowo traciła słuch w wieku adolescencji. Nabyła mowę a zatem 


\section{PROFIL UMIEJĘTNOŚCI SŁUCHOWYCH PACJENTA}

Pacjent: K

Wiek w momencie zaimplantowania: 53

Przyczyna głuchoty: zapalenia uszu
Typ implantu: Med. El C $40+$

Data pierwszego podłączenia procesora mowy: 14 luty 2006

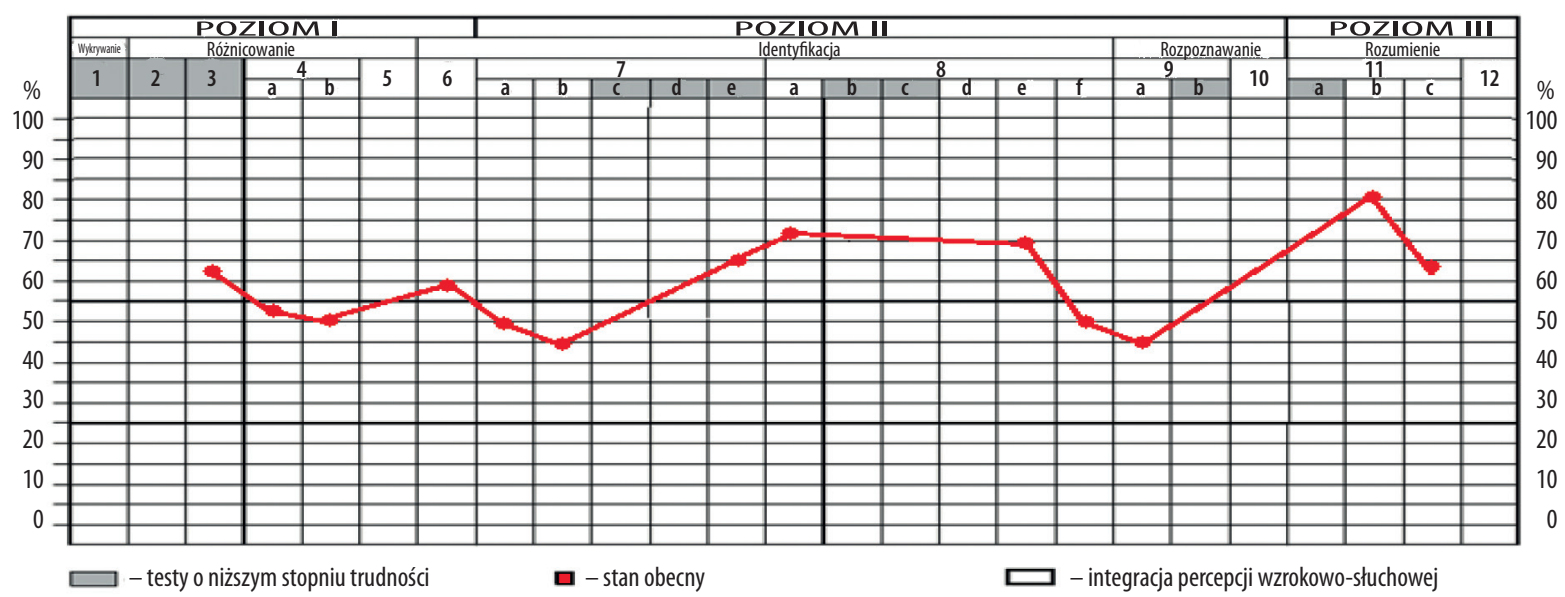

Rycina 1. Profil Umiejętności Słuchowych badanej osoby niesłyszącej [Skarżyński i wsp. 2004]

jej niedosłuch jest o typie postlingwalnym. Obecne występują ślady pamięciowe dzięki którym badana pamięta pewne dźwięki otoczenia oraz mowy. Osoba badana komunikuje się w sposób werbalny z osobami z najbliższego otoczenia, w pracy czy w urzędzie. Jednak często zgłasza kłopoty z komunikowaniem się kiedy rozmówca zbyt szybko mówi a badana nie nadąża za odczytywaniem mowy $\mathrm{z}$ ust. $\mathrm{Z}$ obserwacji wynika, że pacjentka rozumie mowę otoczenia jedynie poprzez odczytywanie mowy z ust. Posługuje się także telefonem komórkowym, pisząc wiadomości „sms”. Oglądając telewizje, raczej odczytuje mowę z ust lub czyta napisy. Pacjentka zgłasza duże trudności w rozumieniu mowy na drodze słuchowej. Pamięta niektóre dźwięki z otoczenia z którymi zdążyła się osłuchać w dzieciństwie np.: słyszy kiedy dzwoni ktoś do drzwi, a także rozpoznaje dźwięk niektórych instrumentów muzycznych np.: skrzypiec. Jednak jak mówi sama większość dźwięków się jej „zlewa”.

Z obserwacji i rozmowy z pacjentką wynika, że niekiedy w komunikowaniu się z otoczeniem towarzyszą jej uczucia niepewności, zakłopotania szczególnie wtedy, gdy rozmawia $\mathrm{z}$ osobami ważnymi rangą lub $\mathrm{z}$ dużą ich grupą. Dodatkowym stresującym aspektem w tym zakresie jest ważność informacji, którą przekazuje. Badana często w takich sytuacjach nie koncentruje uwagi na mówieniu, przez co dochodzi czasami do zakłóceń w komunikowaniu się.

Zjawisko deprywacji słuchowej u badanej osoby niesłyszącej spowodowane jest brakiem stymulacji słuchowej przez długi okres czasu. W przypadku pacjentki przejawia się ona w postaci braku rozumienia mowy na drodze słuchowej. Obecnie badana osoba korzysta z kanału wzrokowo-słuchowego (odczytywanie mowy z ust rozmówcy).

Stwierdza się również w przypadku badanej osoby ograniczenie funkcjonowania pierścienia zwierającego gardło. Dodatkowo występują objawy nadmiernej ruchomości warg przy wymowie nosowej. Wyżej wymienione trudności pacjentki nie są spowodowane bezpośrednimi trudnościami motorycznymi lecz wynikają z braku kontroli słuchowej.

Zdobyte umiejętności słuchowe osoby badanej zostały przedstawione graficznie w postaci Profilu Umiejętności Słuchowych Pacjenta [Skarżyński i wsp. 2004] wskazują na przeciętne osiągnięcia badanej osoby w zakresie dyskryminacji, identyfikacji a także i rozumienia dźwięków mowy i otoczenia. Utworzony profil stanowi punkt wyjścia do skonstruowania indywidualnego programu terapii dla osoby badanej w celu rozwijania umiejętności słuchowych na drodze słuchowej (Rycina 1).

Test Onomatopeje wskazuje, że osoba badana w zakresie identyfikacji (65\%) dokonuje interpretacji wyodrębnionych cech ze zbioru cech akustycznych w górnych granicach wyniku przeciętnego. Z kolei w różnicowanie ( 57\%) wskazuje na trudności badanej osoby w porównywaniu dwóch bodźców słuchowych jako różnych lub takich samych.

Test słuchowego różnicowania głosek (TSRG). Wynik (53\%) ustalono na podstawie badania pacjentki, która odczytywała mowę z ust badającego. Mimo to osiągnięty wynik osoby badanej świadczy o trudnościach w zakresie rozróżniania cech dystynktywnych tj: dźwięczność-bezdźwięczność, ustność-nosowość, twardość-miękkość, opozycja sposobu artykulacji - inaczej stopnia zbliżenia narządów mowy oraz opozycja miejsca artykulacji.

Test „Chiński Język” - ta próba zweryfikowała umiejętności osoby badanej pod względem różnicowania fonemów w którym osiągnęła wynik 52\%. Świadczy to o tym, że u badanej osoby niesłyszącej występują trudności w dyskryminacji fonemów np.: (otło-odło). Częściej zdarzały się błędy dotyczące dźwięczna-bezdźwięczna.

Test identyfikacji 12 dźwięków. Wyniki badań w zakresie identyfikacji dźwięków otoczenia w zestawie otwartym wynoszą 58,33\% a w zamkniętym 91,67\%. Świadczy to o tym, że badana osoba niesłysząca ma większe trudności 


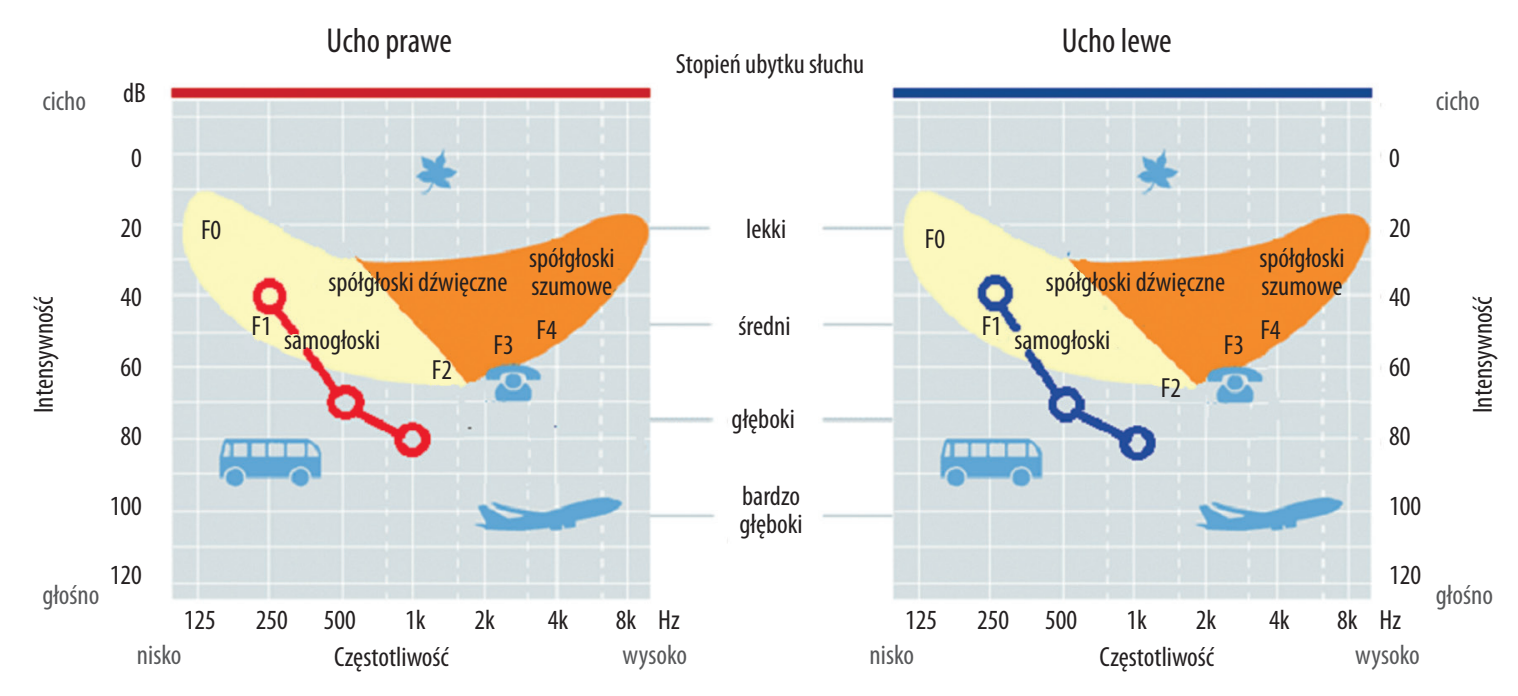

Rycina 2. Naniesione wyniki badanej osoby na wykres obrazujący percepcję mowy (wykres pobrano z http://w1.hearing.siemens. $\mathrm{com} / \mathrm{pl})$

w identyfikacji bodźców akustycznych w zakresie odbioru na drodze słuchowej. Z kolei lepiej radzi sobie w sytuacji gdy słyszy dźwięk a on jest poparty materiałem wzrokowym. Uzyskane wyniki dają obiektywną wiedzę o możliwościach rozpoznawania dźwięków docierających wyłącznie drogą słuchową.

Test skriningowy: $\mathrm{W}$ teście poziomu A badana osoba niesłysząca osiągnęła wynik 50\%. Ten wynik świadczy o tym, że badana ma trudności w zakresie identyfikacji na podstawie długości wyrazu. W ćwiczeniach poziomu B badana osoba niesłysząca osiągnęła wynik $45 \%$. Ten wynik świadczy o tym, że badana ma trudności w zakresie identyfikacji na podstawie długości zdania. W teście poziomu C badana osoba niesłysząca osiągnęła wynik 66\%. Ten wynik świadczy o tym, że badana całkiem dobrze radzi sobie z rozróżnianiem (popartej o kanał wzrokowy) w zakresie wypowiedzi różniących się przede wszystkim drugim formantem, który odpowiedzialny jest za barwę samogłosek. W ćwiczeniach poziomu D badana osoba niesłysząca uzyskała wynik $80 \%$. Ten wynik świadczy o dobrych umiejętnościach w zakresie rozpoznawania popularnych zdań.

W zakresie baterii testów sprawności słuchowej dla osób dorosłych przeznaczonej dla pacjentów z głuchotą postlingwalną, korzystających z implantów badana osoba niesłysząca uzyskała następujące wyniki:

- Identyfikacja samogłosek języka polskiego w sylabach $\mathbf{7 0 \%}$ świadczy to o bardzo dobrej umiejętności rozróżniania samogłosek oprócz i-y.

- Identyfikacja spółgłosek w sylabach - $\mathbf{5 0 \%}$ wynik ten wskazuje na trudności w identyfikacji spółgłosek w sylabach.

- Identyfikacja liczb od 1 do 100 - $\mathbf{4 5 \%}$ wynik ten wskazuje na trudności w zakresie identyfikacji liczb bez względu na natężenie głosu.

- Rozumienie zdań w zestawie otwartym - wynik uzyskany przez osobę badaną to $36 \%$ słów zrozumianych tylko na drodze słuchowej. Badana osoba niesłysząca w niewielkim stopniu odbiera na drodze słuchowej kierowane do niej wypowiedzi.

\section{Analiza realizacji podsystemu fonologicznego}

\section{Cechy segmentalne}

Porównując wyniki audiometrii w wolnym polu z okresu przed zastosowaniem implantu do zakresu częstotliwości i natężeń charakterystycznych dla odbioru mowy należy stwierdzić, że osoba badana odbierała dźwięki tylko i wyłącznie w zakresie niskich częstotliwości, natomiast często średnie i wysokie częstotliwości znajdowały się poza możliwościami odbioru na drodze słuchowej (Rycina 2). Jak widać poniżej badana osoba niesłysząca odbierała tylko tony niskie $250 \mathrm{~Hz}$, akustycznie związane $\mathrm{z}$ takimi cechami mowy jak: intonacja, dźwięczność. Jest to za mało na dyskryminację i identyfikację dźwięków mowy w pełnym zakresie. Brak możliwości słyszenia w zakresie tonów wysokich, wpływało na gorszą słyszalność samogłosek i spółgłosek a to prowadzi do zaburzeń w rozumieniu mowy.

Artykulację samogłosek w przypadku badanej osoby niesłyszącej zilustrowano na podstawie „trójkąta samogłoskowego" przedstawionego na diagramie z parametrami F1 i F2 w porównaniu z normą (Rycina 3.).

Samogłoska ustna a, u osoby badanej w F1 wynosi $893 \mathrm{~Hz}$ a w F2 wynosi $1283 \mathrm{~Hz}$, a zatem mieści się w normie, gdyż badana samogłoska przebiega w paśmie w F1 683-1020 Hz a w F2 - 1130-1570 Hz. Zewnętrzny obraz samogłoski badanej jest prawidłowy i łatwy do wyróżnienia dzięki znacznemu otwarciu ust zarówno w poziomie jak i w pionie $\mathrm{z}$ równoczesnym swobodnym ułożeniem języka na dnie jamy ustnej.

Samogłoska ustna o, u osoby badanej w F1 wynosi 725 $\mathrm{Hz}$ a w F2 wynosi $1172 \mathrm{~Hz}$. Oznacza to, że nie mieści się w normie dla formantów F1 i F2 osób z normalnym słuchem. Wyższy formant F1 świadczy o szerszym kanale głosowym w przodzie jamy ustnej a także o obniżeniu masy języka. Z kolei wartość formantu F2 jest wyższa co może powodować jej uprzednienie. 


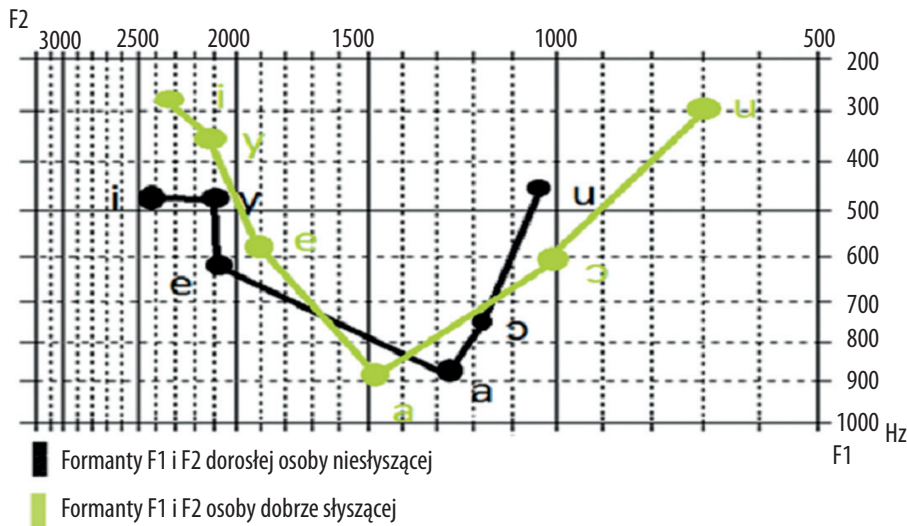

Rycina 3. Trójkąt samogłoskowy osoby badanej - opracowanie własne
Samogłoska ustna e, u osoby badanej w F1 wynosi $614 \mathrm{~Hz}$ a w F2 wynosi $2009 \mathrm{~Hz}$, a zatem mieści się w normie, gdyż badana samogłoska przebiega w paśmie w F1 - 524-630 Hz a w F2 - 1580-2230 Hz. Z trudnością, ale jednak można wyróżnić ją wzrokowo dzięki układowi artykulacyjnemu. Przy wymawianiu samogłoski e masa języka przesunięta jest do przodu, jednak przesunięcie to jest znacznie mniejsze niż w przypadku samogłoski i.

Samogłoska ustna i, u osoby badanej w F1 wynosi $446 \mathrm{~Hz}$ a w F2 wynosi $2400 \mathrm{~Hz}$, a zatem nie mieści się w normie. Badana samogłoska przebiega w paśmie F1 - 188-275 Hz a w F2 - 2090-2840 Hz. Wysoki F1 świadczyć może o szerszym kanale głosowym. Z kolei w F2 jest w normie i charakteryzuje go przedni układ masy języka. O barwie samogłoski i decyduje formant F2. Wzrokowo jest słabo wyróżnialna i przypominająca zewnętrzną artykulację samogłoski y.

Samogłoska ustna y, u osoby badanej w F1 wynosi $446 \mathrm{~Hz}$ a w F2 wynosi $2009 \mathrm{~Hz}$. Formant pierwszy jest nieco wyższy w porównaniu do przebiegów w normie (F1 - 262$391 \mathrm{~Hz}$ ). Formant F2 jest w normie. Świadczy to o tym, że przy wymawianiu samogłoski y masa języka badanej osoby niesłyszącej jest wzniesiona ku górze i przesunięta ku przodowi jamy ustnej. Należy zaznaczyć, że formant pierwszy samogłoski y jest nieco wyższy niż formant pierwszy samogłoski i, natomiast formant drugi y leży nieco niżej niż formant drugi i.

Samogłoska ustna u, u osoby badanej w F1 wynosi $446 \mathrm{~Hz}$ a w F2 1060 Hz. Formant F1 jest wyższy odnosząc go do przebiegu w pasmach $243-338 \mathrm{~Hz}$. Świadczy to o większej szerokości kanału głosowego w przodzie jamy ustnej. Formant F2 jest również wyższy w porównaniu z przebiegiem w pasmach 573-789 Hz. Oznaczać to może, że badana osoba niesłysząca nie przesuwa masy języka w głąb jamy ustnej powoduje to uprzednienie i obniżenie a także nie obserwuje się u niej zaokrąglenia warg.

Trójkąt samogłoskowy badanej osoby niesłyszącej jest znacznie niższy w płaszczyźnie pionowej porównując do wykresu osoby słyszącej. Płaszczyzna pionowa formantu F1 wskazuje na ruchy języka w pionie góra-dół i wielkość otworu wargowego. U badanej osoby niesłyszącej ograniczony jest ruch języka w górę oraz zwężenie otworu wargowego i w związku z tym nie dochodzi do obniżenia częstotliwości formantu F1.
Płaszczyzna pozioma trójkąta jest ograniczona w części samogłosek tylnych, nie są one wyraźnie tylne jak obserwuje się to u osoby słyszącej gdzie ruch języka następuje do tyłu wraz z zaokrągleniem warg co powoduje obniżenie formantu F2. Badana osoba niesłysząca nie wykonuje wyżej opisanych ruchów skrajnych. Samogłoski pod względem wizualnym realizuje poprawnie. Zauważa się poszum nosowy samogłosek ustnych, które podczas ich wymawiania wpływają zasadniczo na nieprawidłowe ich brzmienie. W zakresie różnicowania samogłosek duże trudności badanej osobie niesłyszącej sprawiają samogłoski [i-i]. Związane jest to $\mathrm{z}$ tym, że ta różnica przypada na wysokie częstotliwości, które osoba badana nie odbiera (ok. 2500-3000 Hz). Charakterystyczna w przypadku badanej osoby jest realizacja samogłosek nosowych ว̃ [ou] $\tilde{\varepsilon}$ [ęu ] w sposób hiperpoprawny.

W zakresie spółgłosek realizowanych przez badaną osobę niesłyszącą należy wskazać niepoprawną artykulację spółgłosek sybilantnych [ $\left.\int, 3, \mathrm{t}, \mathrm{G}\right]$. Sposób ich realizacji jest charakterystyczny dla osób z odbiorczym ubytkiem słuchu (dyslalia audiogena, seplenienie przyzębowe). Błędna artykulacja tych spółgłosek występuje wskutek płasko ułożonej przedniej części języka przylegającego mocno do powierzchni wewnętrznej dolnych zębów siecznych, a powietrze przechodzi szerokim strumieniem wytwarzając przytępiony szmer. Występujące zaburzenia syntagmatyczne u osoby badanej obejmują zniekształcenia struktury liniowej wyrazu w postaci określanej jako: redukcje (arówka - żarówka, kura - kua, fukcjonowania funkcjonowania), substytucje (klijęt - klient) a także sporadycznie upodobnienia (prawidłewego - prawidłowego). Wspomniane zniekształcenia ciągu fonicznego wypowiedzi często spowodowane są zbyt szybkim tempem mówienia, a także niedokładnością artykulacyjną. Najczęściej tego typu trudności można zaobserwować podczas mowy spontanicznej.

\section{Cechy suprasegmentalne}

Na podstawie wyników uzyskanych z programu komputerowego Wave Surfer 1.8 stwierdzono nieprawidłowości $\mathrm{w}$ przebiegu linii intonacyjnej u badanej osoby niesłyszącej. Zdania twierdzące wymawiane przez badaną wskazują na monotonną i płaską linię intonacyjną w porównaniu $\mathrm{z}$ przebiegiem linii intonacyjnej osoby $\mathrm{z}$ prawidłowym słuchem gdzie intonacja jest rosnąco-opadająca. Zdania 
przeczące realizowane są przez badaną osobę zdecydowanie różnią się konturem intonacyjnym od realizacji osoby $\mathrm{z}$ prawidłowym słuchem.

W przypadku badanej osoby ciągi są realizowane w sposób monotonny a linia intonacyjna jest porównywalna do konturu intonacyjnego zdań twierdzących. Wykresy przebiegu linii intonacyjnej u badanej osoby niesłyszącej wskazują na występowanie zdań, rozkazujących, wykrzyknikowych i pytających w postaci realizacji zdań twierdzących. Czasami występują wypowiedzi twierdzące i rozkazujące z intonacją zdań pytających. Osoba niesłysząca w porównaniu ze słyszącą nie intonuje w sposób poprawny zdań rozkazujących jako kadencja, zdań wykrzyknikowych w postaci intonacji opadającej a zdań pytających jako antykadencja na co wskazują poniższe wykresy (Ryciny 4-7).

U badanej osoby stwierdza się brak wahań formantu $\mathrm{F}_{0}$ powodujący odbiór melodii mowy jako płaskiej i monotonnej. W opisie zaburzeń prozodycznych zauważono również wyraźną tendencję do skandowania pojedynczych wyrazów, z pauzami międzywyrazowymi. Istotny wpływ na poprawność wymowy badanej osoby miał późny moment wszczepu systemu implantu ślimakowego.

Stwierdzono również nieprawidłowości w przebiegu linii intonacyjnej. Najczęściej jest ona monotonna i płaska. W przypadku realizacji zdań rozkazujących, wykrzyknikowych i pytających występuje w postaci realizacji zdań twierdzących. Osoba niesłysząca w porównaniu z osobą słyszącą nie intonuje w sposób poprawny zdań rozkazujących jako kadencja, zdań wykrzyknikowych w postaci intonacji opadającej a zdań pytających jako antykadencja.

Badania wskazały również zaburzenia akcentu melodycznego oraz dynamicznego zarówno wyrazowego jak i zdaniowego, $\mathrm{z}$ nadmiernym akcentowaniem wybranych wyrazów w zdaniu. Zauważa się także brak obecności akcentu dynamicznego co utrudnia wyróżnianie odpowiednich sylab w wyrazie lub wyrazu w zdaniu. Najczęściej te nieprawidłowości występują w mowie spontanicznej, jednak zdarzają się również przy powtarzaniu i czytaniu.

Biorąc pod uwagę ocenę foniatryczną należy stwierdzić, że głos osoby badanej jest matowy, obłożony, czasami z tendencją do ubezdźwięczniania. Ma on charakter falujący a zatem zaburzona jest zdolność utrzymania fonacji na tym samym poziomie. Wydobywanie głosu u badanej osoby realizowane jest w sposób party. Często towarzyszy temu nadmierne napięcie mięśni szyi i unoszenie ramion. Nastawienie głosu jest twarde, natomiast czas fonacji znacznie skrócony. Zakres głosu jest zawężony. Natężenie głosu cechuje się podwyższonymi wartościami (mowa jest głośna). W badaniu narządu artykulacyjnego stwierdza się odchylenia od stanu prawidłowego w postaci: obniżonej sprawności warg i języka a także nieprawidłową czynność podniebienia miękkiego, czego konsekwencją jest nosowanie otwarte. W zakresie narządu fonacyjnego obserwuje się zaburzenia koordynacji oddechowo-fonacyjnej. Charakterystyczne jest skrócenie fazy wydechowej z współwystępującymi częstymi i zbyt głębokimi, słyszalnymi wdechami [Trochymiuk, 2008 s. 23].
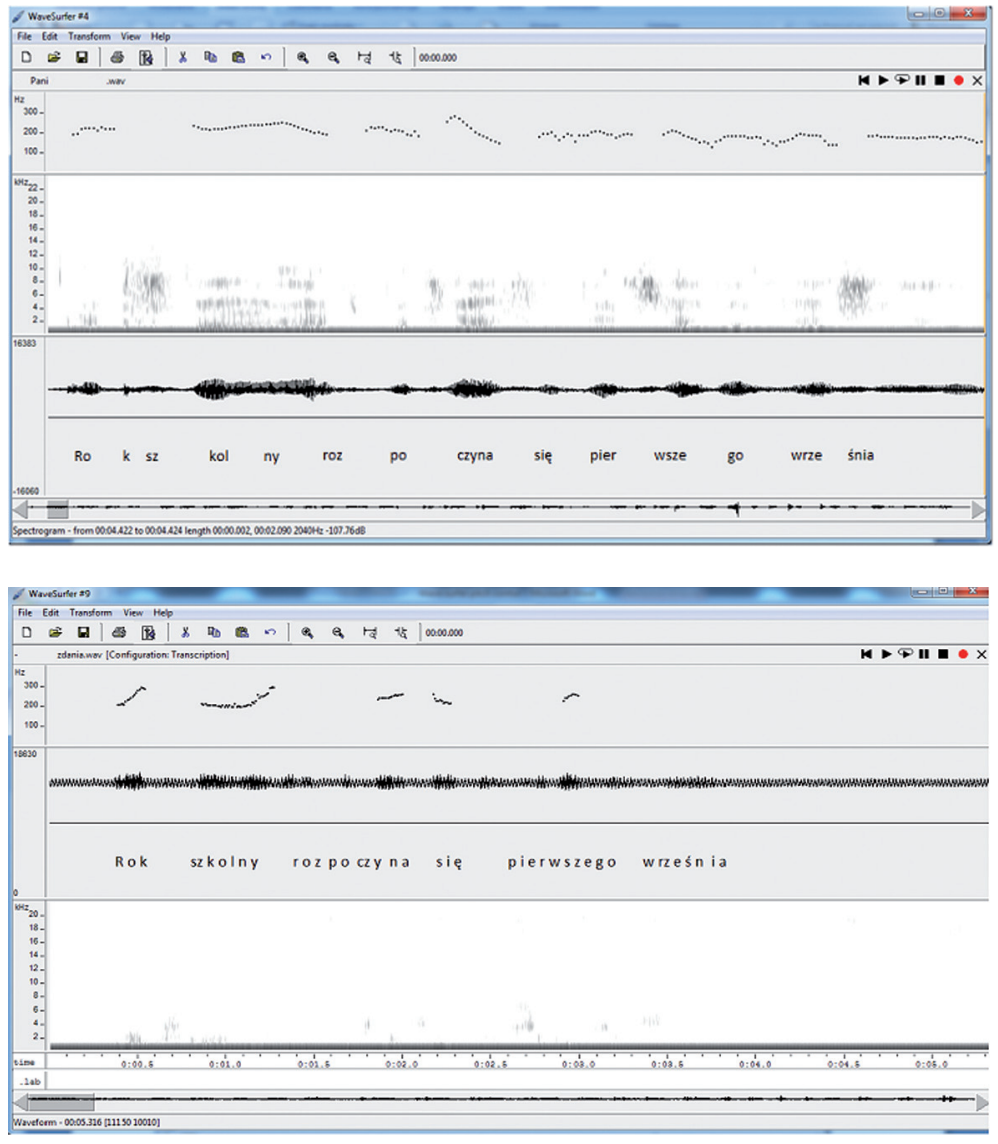

Rycina 4A. Zdanie twierdzące: Rok szkolny rozpoczyna się pierwszego września w wykonaniu badanej osoby niesłyszącej

Rycina 4B. Zdanie twierdzące: Rok szkolny rozpoczyna się pierwszego września w wykonaniu badanej osoby słyszącej 

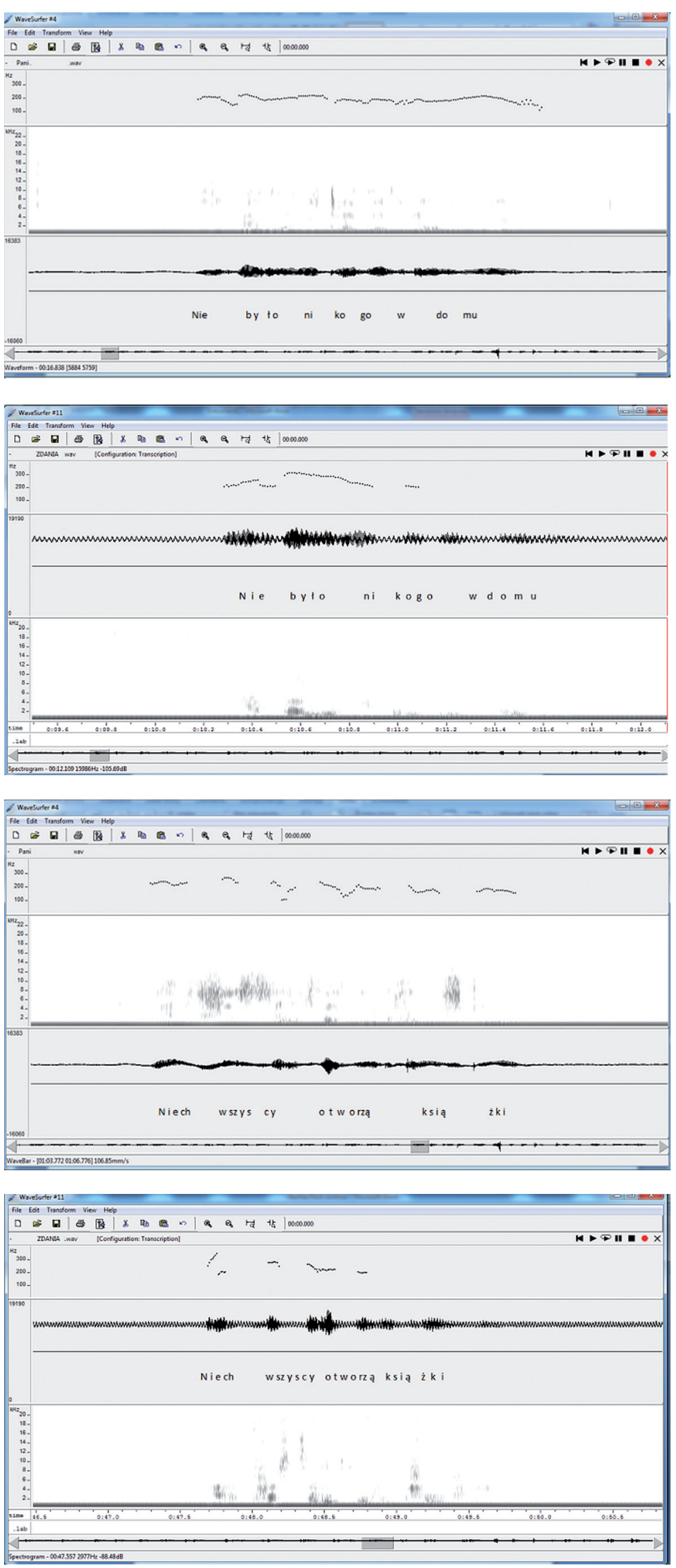

Rycina 5A. Zdanie przeczące: Nie było nikogo w domu. w wykonaniu badanej osoby niesłyszącej

Rycina 5B. Zdanie przeczące: Nie było nikogo w domu. W wykonaniu osoby słyszącej

Rycina 6A. Zdanie rozkazujące. Niech wszyscy otworzą książki. Wykonane przez badaną osobę niestyszącą

Rycina 6B. Zdanie rozkazujące. Niech wszyscy otworzą książki. Wykonane przez osobę słyszącą 

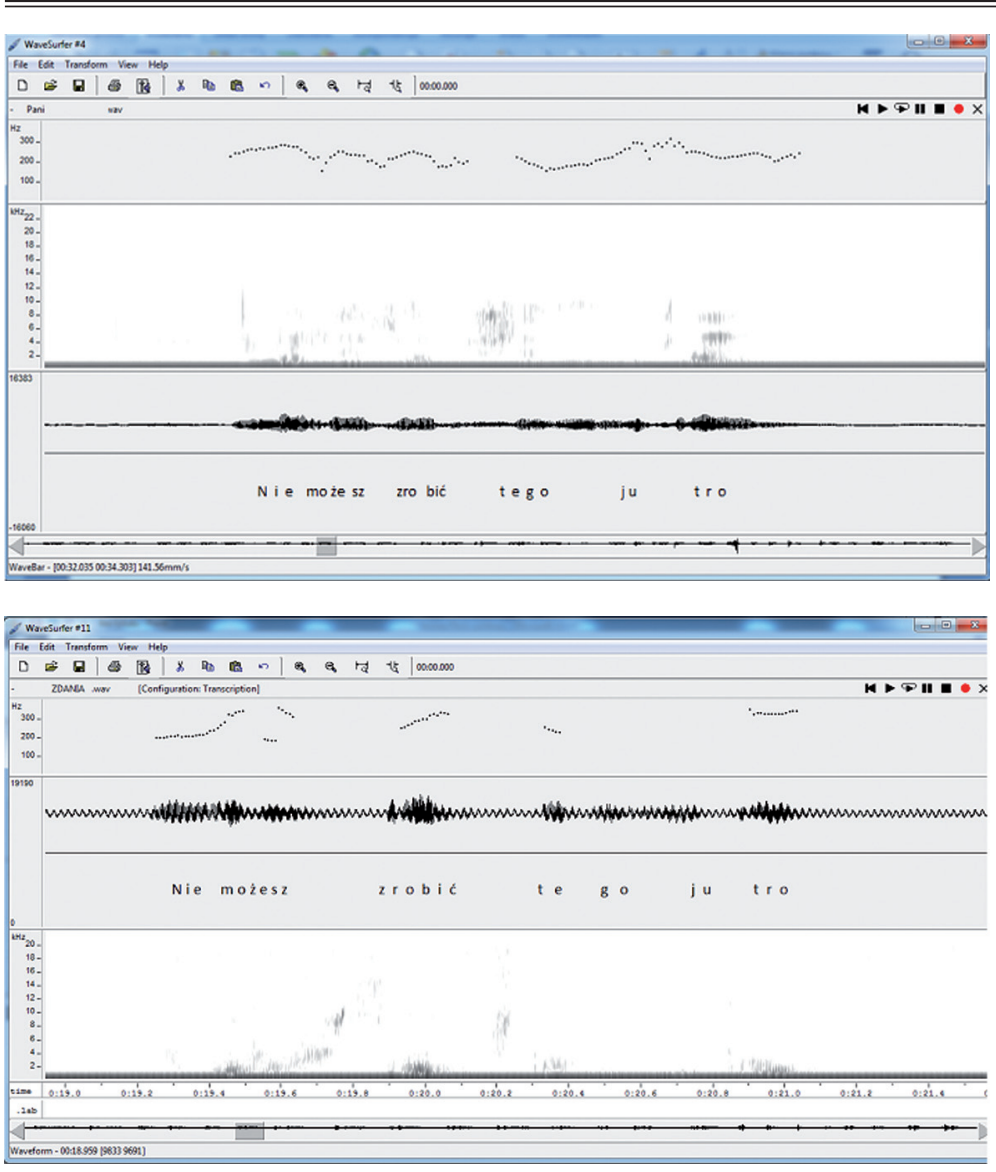

Rycina 7A. Zdanie pytające. Nie możesz zrobić tego jutro? Wykonane przez badaną osobę niesłyszącą

Rycina 7B. Zdanie pytające. Nie możesz zrobić tego jutro? Wykonane przez osobę styszącą

\section{Podsumowanie}

Zjawisko deprywacji słuchowej jest ograniczeniem odbioru bodźców słuchowych, które najczęściej jest konsekwencją długotrwałego niedosłuchu. Może wystąpić ona przy zbyt późnym lub nieodpowiednio protezowanym odbiorczym ubytku słuchu. Przywrócenie prawidłowej czułości słuchu powoduje przez pewien okres czasu występowanie zaburzeń wyższych funkcji słuchowych.

Postlingwalny ubytek słuchu dotyczy osób, które prawidłowo słyszały i nabyły mowę do 7 roku życia, ale na skutek chorób zakaźnych, zapalnych, przewlekłych czy urazów doszło do uszkodzenia narządu słuchu w okresie adolescencji. Bardzo ważne jest, aby ten ubytek słuchu był jak najszybciej protezowany i włączony w program treningu słuchowego dla zachowania mowy, która rozwinęła się na drodze fizjologicznej.

Dzisiejsze możliwości medyczne stwarzają szansę kompleksowego leczenia zachowawczego i operacyjnego wrodzonych i nabytych zaburzeń narządu słuchu, w tym m.in.: leczenie i protezowanie wad słuchu, leczenie operacyjne głuchoty i głębokiego niedosłuchu za pomocą systemu implantów ślimakowych, leczenie operacyjne wad słuchu przy użyciu wszczepialnych implantów ucha środkowego.

Istotnym osiągnięciem współczesnej medycyny jest system implantu ślimakowego -rodzaj elektronicznej protezy słuchowej, która zastępuje uszkodzoną część narządu odbiorczego. Funkcją implantu, który jest wszczepiany choremu z całkowitą głuchotą, głębokim niedosłuchem lub częściową głuchotą jest odbiór dźwięków z otoczenia a zwłaszcza mowy. Przez stymulacje akustyczno-elektryczną odbywa się dostarczanie dźwięków do centralnych ośrodków słuchowych, które odpowiedzialne są za odbieranie dźwięków jako wrażeń słuchowych [Skarżyński, 2010]. System implantu ślimakowego jest zbudowany tak, aby mógł być noszony stale w warunkach codziennego życia oraz stymulować elektrycznie nerw słuchowy.

Biorąc pod uwagę wyniki badań należy stwierdzić, że zjawisko deprywacji słuchowej u badanej osoby wystąiło na skutek uszkodzenia narządu słuchu powodując ubytek słuchu w okresie adolescencji. Pacjentka nie korzystała $\mathrm{z}$ aparatów słuchowych czego konsekwencją było ograniczenie percepcji słuchowej a także stopniowa utrata przetwarzania słuchowego mowy. Przejawia się to brakiem rozumienia mowy na drodze słuchowej. Deprywacja słuchowa osoby badanej jest również konsekwencją późnej operacji wszczepienia systemu implantu ślimakowego. Aktualnie badana osoba niesłysząca opiera się głównie na kanale wzrokowo-słuchowym. Mowa jej jest charakterystyczna dla osób z postlingwalnym ubytkiem słuchu. Występują zaburzenia artykulacji - dyslalia audiogenna, a także zakłócenia elementów prozodycznych wypowiedzi: intonacji, akcentu i rytmu.

Tworząc ramowy program terapii wzięto pod uwagę wyniki badań diagnostycznych bazując na Profilu Umiejętności Słuchowych [Skarżyński i wsp.. 2004] i posłużono się nim jako punktem wyjścia do tworzenia procesu rehabilitacji. 
Metody terapii jakie zastosowano w przypadku osoby dorosłej z objawami deprywacji słuchowej to przede wszystkim trening słuchowy bazujący na dyskryminacji i identyfikacji, a także rozumieniu mowy bodźców akustycznych na drodze słuchowej. Terapia ta nie przyniosła jednak oczekiwanych rezultatów ze względu na zjawisko deprywacji i brak możliwości prowadzenia intensywnej terapii. Dlatego należy kontynuować program terapii w postaci intensywnego treningu słuchowego a także ćwiczeń logopedycznych z zakresu emisji głosu, techniki mówienia począwszy od relaksacji, wypracowania właściwej postawy ciała, poprzez ćwiczenia oddechu, fonacji i artykulacji aż do ćwiczeń poprawnej prozodii wypowiedzi.

\section{Piśmiennictwo:}

1. Mikołajewski R.; Zjawisko deprywacji słuchu - problem większości protezowanych pacjentów. Audiofonologia, 2000; XVII: 159-64

2. Pilch T., Bauman T.: Zasady badań pedagogicznych. Strategie ilościowe i jakościowe. Warszawa. Wyd. Akademickie „Żak”, 2001

3. Skarżyński H., Szuchnik J., Mueller-Malesińska M.: Implanty ślimakowe-rehabilitacja. Warszawa. Wyd. Stowarzyszenie Przyjaciół Osób Niesłyszących i Niedosłyszących, 2004

4. Skarżyński H.: Wszczepy ślimakowe i pniowe. A. Pruszewicz., A. Obrębowski (red.). w: Audiologia Kliniczna - Zarys. Poznań: Wyd. Naukowe Uniwersytetu Medycznego, 2010
5. Szczepankowski B.: Fonetyka akustyczna, audytywna i wizualna. Wybrane zagadnienia. Warszawa. Wydawnictwo Uniwersytetu Warszawskiego, 1985

6. Szuchnik J., Święcińska A.: Narzędzia oceny postępów rehabilitacji u dzieci po wszczepieniu implantów ślimakowych. Audiofonologia, 1999; XV: 124-28

7. Szuchnik J.: Proces nabywania oraz pomiar umiejętności słuchowych i pacjentów implantowanych w kolejnych etapach rehabilitacji. Audiofonologia, 2002; XV: 124-28

8. Trochymiuk A.: Wymowa dzieci niesłyszących. Analiza audytywna i akustyczna. Lublin. Wydawnictwo Uniwersytetu Marii Curie-Skłodowskiej, 2008

9. Wierzchowska B.: Wymowa Polska. Warszawa. Państwowe Zakłady Wydawnictw Szkolnych, 1971 